\title{
ULAMA AND UMARA IN GOVERNMENT OF INDONESIA: A Review Relations of Religion and State
}

\author{
Doli Witro \\ State Islamic University (UIN) Sunan Gunung Djati Bandung, Indonesia \\ Jl. A. H. Nasution No. 105, Cipadung, Kecamatan Cibiru, Kota Bandung, Jawa Barat, 40614 \\ E-mail: doliwitroo1@gmail.com
}

\begin{abstract}
Indonesia is well-known as a Muslim majority. However, this does not make Indonesia as an Islamic country. The relationship between religion and state in Islam is fairly interpretive and it nowadays still becomes a debate. The government system applied in this country is democratic. Besides, there has to freedom for the ulama in preaching without being limited by space and time. A number of ulama are currently being persecuted and intimidated that impacts to the lecture to be either stopped, postponed, or even canceled. At this part, the role of the umara (government) is required in enforcing the applicable law and also maintaining security and order in society. This paper aims to highlight the relationship between religion and state in Indonesian by observing the position of the ulama and the role of the umara in terms of Indonesian government. This paper used a qualitative approach to literature research. The data in this study were obtained from library materials. Data analysis methods used in this study were data reduction, data presentation, and conclusion. The results of the analysis showed that in Indonesia there is a separation between religion and state as the secularistic paradigm. However, it is not completely secularistic because in national legal system there is also a transformation of Islamic law. Religious and state affairs are not able to be separated, so are ulama and umara. It is because the state will experience a crisis in religious knowledge without ulama. Otherwise, without umara, religion cannot be implemented correctly within the country.
\end{abstract}

Keyword: ulama; umara; state; religion.

\begin{abstract}
Abstrak: Indonesia merupakan negara yang berpenduduk mayoritas Islam. Namun bukan berarti Indonesia adalah negara Islam. Hubungan agama dan negara dalam Islam cukup banyak penafsiran. Dalam Islam, hal ini masih menjadi perdebatan sampai saat ini. Sistem pemerintahan yang diterapkan di Indonesia saat ini adalah sistem demokrasi. Terlepas dari sistem tersebut, tentu harus memberikan kebebasan para ulama dalam berdakwah tanpa dibatasi oleh ruang dan waktu. Saat ini, ada ulama yang dipersekusi dan diintimidasi sehingga ceramah yang hendak dilaksanakan terpaksa dihentikan, ditunda, bahkan dibatalkan. Disinilah diperlukan peran umara (pemerintah) dalam menegakkan hukum yang berlaku dan juga menjaga keamanan serta ketertiban di masyarakat. Tulisan ini bertujuan menyoroti relasi agama dan negara dalam konteks Indonesia dengan melihat kedudukan ulama dan peran umara dalam pemerintahan Indonesia. Tulisan ini menggunakan metode pendekatan kualitatif yang bersifat penelitian pustaka. Data-data dalam penelitian ini diperoleh dari bahan-bahan yang bersifat pustaka Metode analisis data yang digunakan dalam penelitian ini yaitu reduksi data, penyajian data dan penarikan kesimpulan. Hasil analisis menunjukkan di Indonesia terjadi pemisahan antara agama dan negara sebagaimana paradigma sekuleristik. Tetapi disini tidak sepenuhnya sekularistik karena pada hukum nasional Indonesia juga terjadi transformasi hukum Islam. Urusan agama dan negara tidak dapat dipisahkan. Begitu juga dengan ulama dan umara tidak dapat dipisahkan karena tanpa ulama maka negara akan mengalami krisis ilmu agama dan tanpa umara maka agama tidak bisa diterapkan secara sempurna dalam suatu negara.
\end{abstract}

Kata kunci: ulama; umara; negara; agama.

\section{Introduction}

Indonesia is a country with a majority Muslim population. But that does not mean that Indonesia is an Islamic state because Indonesia consists of several religions protected by the country's constitution. ${ }^{1}$ As quoted by global religious futures,

${ }^{1}$ Mudrik Al Farizi, "Konfigurasi Pemikiran Relasi Islam Dan Negara Di Indonesia," Al Mabsut: Jurnal Studi Islam Dan Sosial 10, no. 2 (2016), p. 1, https://ejournal.iaingawi.ac.id/index.php/ almabsut/article/view/158. 
the total population of Indonesia in 2010 is Muslim as many as 209.12 million people or equivalent to $87.17 \%$ of the total population reaching 239,89 million inhabitants. In 2020, Indonesia's Muslim population is predicted to increase to 256.82 million. ${ }^{2}$

The data above shows that a country with a Muslim majority is not necessarily an Islamic state. The relationship between religion and state in Islam has quite a lot of interpretations, although Islam is believed to be able to be a guide in various aspects of life, including in-state and political order. In Islam, this is still a difference today. ${ }^{3}$ All this is inseparable from the paradigmatic thinking of experts about the relationship or the relationship between religion and the state.

The government system implemented in Indonesia today is democratic. Democracy comes from the ancient Greek, which consists of two syllables, namely demos and kratos. Demos means government and kratos mean people. So democracy can be interpreted as the sovereignty of government in the hands of the people. ${ }^{4}$ The democratic system has been implemented in Indonesia since the founding of the country in 1945. But in its development, the democratic system has

${ }^{2}$ Katadata.co.id, "Jumlah Penduduk Indonesia Menurut Agama (2010-2050)," 2019, https://databoks.katadata.co.id/ datapublish/2019/09/24/berapa-jumlah-penduduk-muslimindonesia?utm=viva43v3r, accessed on February, 25, 2020.

3 Zaprulkhan, "Relasi Agama Dan Negara Dalam Perspektif Islam," Walisongo, vol. 22, no. 1 (2014), p. 106, https://doi. org/10.21580/ws.22.1.261; In fact, according to Azra, the debate until now has not yet been completed. Azyumardi Azra, Pergolakan Politik Islam (Jakarta: Paramadina, 1996) p. 1; Bahtiar Effendy, "Islam and the State in Indonesia: Munawir Sjadzali and the Development of Anew Theological Underpinning of Political Islam," Studia Islamika, vol. 2, no. 2 (1995),pp. 97-121, https://doi.org/10.15408/sdi.v2i2.836.

${ }^{4}$ Masyukuri Abdillah, Demokrasi Di Persimpangan Makna; Respon Intelektual Muslim Indonesia Terhadap Konsep Demokrasi 1966-1930 (Yogyakarta: Tiara Wacana, 1999), p. 7; Denis G. Arnold, "Corporations and Human Rights Obligations," Business and Human Rights Journal, vol. 1, no. 2 (2016), pp. 255-75, https:// doi.org/10.1017/bhj.2016.19; Matt Edge, "A Theory of Freedom," European Journal of Political Theory, vol. 12, no. 4 (2013), pp. 368-87, https://doi.org/10.1177/1474885112473721; Gunnar C. Aakvaag, "3 A Democratic Way of Life: Institutionalizing Individual Freedom in Norway," Democratic State and Democratic Society, 2018, pp. 48-75, https://doi.org/10.1515/9783110634082004; Marlene Mauk, "Disentangling an Elusive Relationship: How Democratic Value Orientations Affect Political Trust in Different Regimes," Political Research Quarterly,vol. 73, no. 2 (2020):pp. 366-80, https://doi.org/10.1177/1065912919829832. experienced several patterns of change. 5 Apart from the democratic system applied in Indonesia, of course, it must provide the freedom of ulama in preaching without being limited by space and time.

At present, some ulama are executed and intimidated so that the lectures to be held must be stopped, postponed, and even cancelled. This made the ulama unable to convey Islamic dakwah, as experienced by Abdul Somad. ${ }^{6}$ Deputy Secretary General of the Indonesian Ulama Council (MUI), Teuku Zulkarnain stressed that there were no concrete steps from the government to stop this action and there were legal inequalities in the handling of the persecution of ulama. The perpetrators of the abuse currently does not get a transparent judicial process.? This is where the role of umara (government) is needed in enforcing applicable laws and also maintaining security and order in society. Ulama are seen as occupying positions and holding religious authority after the Prophet Muhammad passed away. Therefore, ulama occupy a very important place in Islam and the lives of Muslim communities. ${ }^{8}$

Ulama are the heirs of the prophets in conveying the message of Islam. In social life, the cleric has the task of solving many people's problems with his religious knowledge based on

${ }^{5}$ Masa Demokrasi Liberal (1950-1959); Masa Demokrasi Terpimpin (1959-1965); Pelaksanaan Demokrasi Masa Orde Baru (1966-1998); Pelaksanaan Demokrasi Transisi (1998-1999); and Demokrasi Masa Reformasi (1999-Now). Yogi Supriadi, "Hubungan Agama Dan Negara Dalam Perspektif Aksi Bela Islam," Jaqfi: Jurnal Aqidah Dan Filsafat Islam,vol. 1, no. 2 (2017),pp. 42-43, https://doi.org/10.15575/jaqfi.v1i2.1713.

${ }^{6}$ Abdul Somad canceled lectures in several areas in East Java (in Malang, Solo, Boyolali, Jombang and Kediri), Central Java (in Grobongan, Kudus, Jepara, and Semarang), and Yogyakarta. Abdul Somad admitted that the cancellation was carried out because of threats and intimidation towards the activity. By considering the committee's burden, the psychological condition of the congregation, and himself, Abdul Somad chose to cancel the preaching. Merdeka.com, "Ustaz Abdul Somad Sebut Diintimidasi \& Batalkan Ceramah Di Jawa, Ini Kata Polisi," 2018, https://www.merdeka.com/peristiwa/ ustaz-abdul-somad-sebut-diintimidasi-batalkan-ceramah-di-jawaini-kata-polisi.html, accessed on February, 22, 2020.

7 Kiblat.net, "Evaluasi 2017, Persekusi Ulama Hingga Pembubaran Pengajian Jadi Sorotan,” 2017, https://www.kiblat. net/2017/12/31/evaluasi-2017-persekusi-ulama-hingga-pembubaranpengajian-jadi-sorotan/, accessed February, 8, 2020.

${ }^{8}$ Ahmad Nur Ismail, "Ulama Dan Pendidikan Islam Klasik (Kajian Ulama, Status Sosial, Kekuasaan, Pendidikan, Dan Gerakan Intelektual)," Jurnal Media Pendidikan Agama Islam, vol. 1, no. 1 (2014), p. 87, http://ejournal.kopertais4.or.id/susi/ index.php/jmpai/login. 
the Quran and Hadith. Ulama also must teach and explain the contents of Allah revealed to the public. ${ }^{9}$ Ulama are valued for their knowledge and warasatul ambiya', loved for their closeness to Muslims, respected for their honesty and sincerity, their firmness and wisdom in resolving problems faced by the community. ${ }^{10}$ In the community, ulama are essesntially needed because they are legitimate interpreters of the original sources of Islamic teachings, namely Al-Quran and Hadith. ${ }^{11}$

This paper discusses several elements that describe and answer problems, such as the relationship between religion and state in the Indonesian context. Then this paper also discusses the position of ulama and umara in the Indonesian government. This issue needs to be discussed because it is concerned that it will harm Islamic dakwah's development. This paper aims to highlight the relationship between religion and state in the Indonesian context by looking at the ulama's position and the umara's role in the Indonesian government.

\section{Method}

This paper uses a qualitative approach to literature research. This study's data were obtained from library materials from books, scientific articles published in journals, and internet websites related to the issues being studied. The data obtained were presented in a narrative-descriptive manner. The data analysis method used in this research is data reduction, data presentation, and conclusion drawing. ${ }^{12}$

\section{Ulama and Umara}

The word ulama of the plural form noun of in Arabic, which is interpreted as 'alim is derived

9 Nurseri Hasnah Nasution, “Komunikasi Dakwah Ulama Sumatera Selatan (Studi Terhadap Jenis-Jenis Komunikasi Dakwah K. H. Muhammad Zen Syukri)," Jurnal Komunikasi Islam Dan Kehumasan (JKPI), vol. 2, no. 1 (2018), p. 17, https:// doi.org/10.19109/jkpi.v2i1.2750.

10 Sholeh Fikri, "Posisi Ulama Dalam Pemerintahan Kota Padangsidimpuan," TAZKIR: Jurnal Penelitian Ilmu-Ilmu Sosial Dan Keislaman, vol. 2, no. 1 (2016), p. 69, https://doi.org/10.24952/ tazkir.v2i1.402.

${ }^{11}$ Ahmad Nur Ismail, “Ulama Dan Pendidikan Islam..., p.87

${ }_{12}$ Matthew B. Miles and A. Michael Huberman, Qualitative Data Analysis (a Source Book of New Methods) (Beverly Hills: Sage Publications, 1984), pp. 21-24. from the verb 'alima means to know or be knowledgeable. ${ }^{13}$ In Indonesian, the word becomes a singular form, a person who is an expert in the Islamic religion. The name ulama commensurate with ulul albâb is referred to in the Quran to mean wise people ${ }^{14}$-see the Quran surah AsySyu'ara [26]: 197, surah Fâthir [35]: 28-. While terminologically, according to Wahbah Zuhayli, ulama are people who are very afraid of Allah, do not want to violate Allah commands and always keep themselves from disobedience, and they can analyze the universe and also events that occur in life for the interests of the world and the hereafter. ${ }^{15}$ While umara is the plural of the word amir which means leader. The word amir commensurate with the phrase ulul amri in the Quran means a person who holds influence (authority) or conducts the affairs of the people ${ }^{16}$ -see the Quran surah al-Nisâ[4]: 59 and 83-.. According to Muhammad Chirzin, ulul amri is a person who handles various issues of society, can make decisions on these issues and various other issues, and those who have power or people who are responsible for the people they lead. ${ }^{18}$ Ulul Amri is the successor to the leadership of Rasulullah P.B.U.H. Therefore, the first thing that must be possessed by the successor to the direction of the Prophet is faith. Because without faith in Allah and His Messenger, a leader cannot protect his people to worship Allah. ${ }^{19}$ The ulama also agreed that ulul amri meant the leader (umara). ${ }^{20}$

${ }^{13}$ Ibnu Manzur Jamal al-Din Mohammad, Lisan Al-Arab, (Kairo: al-Dar al-Misriyah, n.d.), Juz 15, p. 311; Muhammad Qasim Zaman, The Ulama in Contemporary Islam, Custodians of Change (Princeton \& Oxford: Princeton University Press, 2002), p. 258.

14 Muhammad Chirzin, "Ulama Dan Umara Dalam Perspektif Al-Qur'an,” 2020, http://malang.muhammadiyah.or.id/ content-133-sdet-ulama-dan-umara-dalam-perspektif-alqur'an. html, accessed 9 February 2020.

15 Nasution, "Komunikasi Dakwah Ulama Sumatera Selatan (Studi Terhadap Jenis-Jenis Komunikasi Dakwah K. H. Muhammad Zen Syukri)," p. 17

${ }^{16}$ Muhammad Chirzin, "Ulama Dan Umara..., accessed on February 09, 2020.

17 Hamka, Lembaga Hidup (Jakarta: Republika Penerbit, 2016), p. 87.

${ }^{18}$ Muhammad Chirzin, "Ulama Dan Umara..., accessed on February 09, 2020.

19 Yunahar Ilyas, Kuliah Akhlaq (Yogyakarta: Lembaga Pengkajian dan Pengalaman Islam (LPPI), 1999), p. 248.

${ }^{20} \mathrm{Al}$-Mawardi, Al-Ahkam Al-Sulthaniyah (Kuwait: Maktabah Dar Ibnu, 1989), p. 5. 
According to M. Quraish Shihab the characteristics of the ulama are: First, Muslims. Secondly, understand the Islamic Sharia in kaffah (overall) with the Quran and Hadith. Third, become uswah (example). Fourth, khasysyah (fear) of Allah. Fifth, carrying out Islamic da'wah or amar ma'ruf nahi mungkar. Sixth has the characteristics of the prophet, namely shiddiq, amanah, tabligh, fathanah. ${ }^{21}$

Imam al-Ghazali classified the ulama into two types; First, ulama of the Hereafter are ulama who practice the Quran, Hadith and their knowledge, give uswah (example), simple, zuhud, do not come to the authorities and rich people, they get pure glory from Allah, do not pursue the world, do not sell religion, knowing the beauty of the hereafter and the modesty of the world in life. Secondly, ulama su' (evil ulama), heinous ulama or worldly ulama, namely ulama indulge in lust, criticize the truth of the Quran and Hadith, live lavishly, sell religion, come to the authority (rich people), have knowledge but does not benefit others, ambitions with the world and its culture, forgetting the afterlife, does not practice the Quran and Hadith. ${ }^{22}$

Thus the clerical term is attached to a person not through a formal process, but through recognition after going through a long process in society itself where the elements of ulama in a person in the form of integrity, scientific quality and credibility of honest loyalty and social responsibility are proven. ${ }^{23}$

According to al-Mawardi the leader's obligations include ten things, as follows:

1) maintain the application of true religion; 2) applying the law in every problem that occurs somewhat; 3) protect national security so that people can move freely and not be haunted by fear; 4) enforce criminal law so that citizens' rights are protected; 5) guarding the country's borders with a sound security system so that it can ward off enemy attacks; 6) jihad to fight the enemy; 7) take tax from zakat from citizens by the provisions of the Sharia; 8 ) distributing Baitul Mall

\footnotetext{
${ }^{21}$ M. Quraish Shihab, Membumikan Al-Qur'an (Bandung: Mizan, 1995), pp. 382-388.

${ }^{22}$ Al-Ghazali, Intisari Ihya 'Ulumiddin, (Penerjemah) Junaidi Ismaiel (Jakarta: Serambi Semesta Distribusi, 2016), pp. 45-48.

${ }^{23}$ Ahmad Nur Ismail, "Ulama Dan Pendidikan Islam..., p. 89
}

funds correctly and on time; 9) employ trustworthy and capable people in their fields; 10) monitor the developments directly happening to its citizens and not just entrust it to their representatives so they can have more time to enjoy the world or to worship. ${ }^{24}$

In this case, umara must support the ulama in conveying Islam by providing freedom of movement so that the community can take knowledge from the ulama. With this collaboration, the system of government in a country and also the science of religion owned by its people can run well. The balance created by the correlation of ulama and umara will reduce social inequality, create harmony and peace in society. ${ }^{25}$

\section{Religion and State}

Religion is a rule that regulates the human condition, both about something mysterious that they do not know and about character and manners to live together. ${ }^{26}$ According to Zakiyah Daradjat, religion is a process of human interaction with something that is believed, if something is higher than him and anything in the world. ${ }^{27}$ In this life, religion functions as a system that contains specific regulations. In general, these regulations become a reference to behave in line with the religious beliefs.

Religion is also influential as a person's impulse to do an action because an action carried out against a background of knowledge will have an element of holiness and obedience. This connection will give effect to someone in doing something. ${ }^{28}$ Whereas the state is the organization or the highest body that holds power in regulating something related to the interests of many people and must protect and improve the welfare of the people within it.29

${ }^{24}$ Muhammad Chirzin, "Ulama Dan Umara..., accessed on February 09, 2020.

${ }^{25}$ Abd. Wahid, "Pola Peran Ulama Dalam Negara Di Aceh," Madania, vol. 17, no. 1 (2013): p. 85-92, https://doi.org/10.29300/ madania.v17i1.2845.

${ }^{26}$ Faisal Ismail, Paradigma Kebudayaan Islam: Studi Krisis Dan Refleksi Historis (Yogyakarta: Titian Ilahi Press, 1997), p. 28.

27 Zakiyah Daradjat, Ilmu Jiwa Agama (Jakarta: Bulan Bintang, 2005), p. 10.

${ }^{28}$ Allan Menzies, Sejarah Agama-Agama (Yogyakarta: Forum, 2014), p. 318-21.

${ }_{29}$ Ulil Albab, "Studi Pemikiran Mohammad Natsir Tentang 
The state is an essential concept in political science. The state becomes the area of study because there are political struggle and power that is most easily found. The country is an integration of political power. The state determines the ways and limits of power that can be used in social life both by individuals and groups and by the country itself. ${ }^{30}$

Ulama and umara with religion and state do have different understandings. But within these four elements, there is a close and interrelated relationship. Ulama are people who practice and teach religious values to the community while umara is the authority of government in a country. From this, it can be seen, no matter what, the understanding of religion by people in a nation depends on the ulama who teach religious values. Likewise with the state, the government depends on the umara who runs the government honestly, reasonably, trustworthy, and wise in a country.

\section{Relation between Religion and the State in the Indonesian Context}

The concept of the state gets a special place when viewed from the scope of Islamic scientific treasures. The country has become a study that is considered quite essential and central since the beginning of the development of political science. ${ }^{31}$ Regarding the relation between religion and the state in Islamic history, there is no specific provision on what the form and concept of the country should be. This is where the various interpretations and attempts at interpreting arise. ${ }^{32}$ When viewed from history, the forerunner to an Islamic state, though in a straightforward form and not mentioned legally (formally), can be seen from the Hudaybiyah treaty (Medina Charter). ${ }^{33}$

Islam Sebagai Dasar Negara" (UIN Walisongo Semarang, 2016), p. 19.

30 Abu Bakar Abyhara, Pengantar Ilmu Politik (Yogyakarta: Ar-Ruzz Media, 2010), p. 229-30.

${ }^{31}$ Rijal Mumazziq Zionis, "KONSEP KENEGARAAN DALAM ISLAM: Perdebatan Relasional Yang Tak Kunjung Tuntas," Falasifa, vol. 1, no. 2 (2010), p. 113, https://jurnalfalasifa.files.wordpress. com/2012/11/8-rijal-mumazziq-zionis-konsep-kenegaraan-dalamislam-perdebatan-relasional-yang-tak-kunjung-tuntas.pdf.

${ }^{32}$ Abd. Salam Arief, "Relasi Agama Dan Negara Dalam Perspektif Islam," Hermeneia: Jurnal Kajian Islam Interdisipliner, vol. 2, no. 2 (2003), p. 279, http://digilib.uin-suka.ac.id/8422/.

33 Zionis, "KONSEP KENEGARAAN DALAM ISLAM: Perdebatan Relasional Yang Tak Kunjung Tuntas," p. 115.
In general, there are at least three paradigms of thought about the relationship between religion and state. ${ }^{34}$ First, the model which states that Islam has nothing to do with the state because Islam does not regulate the life of the country (government).This paradigm is also called the secularistic standard. The figures who support this concept are 'Ali Raziq and Thaha Husein; Second, the model which considers that Islam is a complete religion, encompassing everything, including the problem of the state or political system, this paradigm is called the formalistic (intergalactic) standard. The figures who support this paradigm are Hassan al-Banna, Sayyid Qutb, Rashid Ridha, and Abu al-A'la al-Maududi.

Third, the paradigm which rejects the view that Islam only regulates the relationship between man and his Creator and rejects the opinion that Islam encompasses everything. This paradigm argues that Islam does not cover everything, but includes a set of principles and values for community life, including the state ${ }^{35}$; this paradigm is also called a symbiotic (substantial) model. The figures who support this paradigm are Muhammad 'Abduh and Muhammad Haikal.

In the Indonesian context, experts Nurcholish Madjid, Harun Nasution, Rusydi Hamka, Abdurrahman Wahid, Muhammad Natsir, and even Seokarno- have different views about the relations of religion and the state.

In the 1940 s to 1990 , there were often heated debates on the issue. Though this debate has never found common ground, namely in the Jakarta Charter concept, which was then annulled the day after independence. Efforts to resolve the issue at the constituent assembly foundered midway because it was interrupted by Sukarno through the 1959 Decree. Likewise, what had happened during the New Order administration, which deliberately covered up possible discussions on the issue. ${ }^{36}$

Beginning with the debate between Muhammad Natsir and Sukarno, finally, Islam sought its way in its social and political life in a way that could be

34 Munawir Sjadzali, Islam Dan Tata Negara (Jakarta: Universitas Indonesia, 1993), p. 1-2.

35 Efrinaldi, "Spektrum Fikih Siyasah Dan Dinamisasi Politik Islam Di Indonesia," Madania,vol. 17, no. 1 (1991), pp. 19-30, https://doi.org/10.29300/madania.v17i1.2839.

${ }^{36}$ Mudrik Al Farizi, “Konfigurasi Pemikiran Relasi Islam..., p. 2. 
considered formalistic, so that its presence was not only felt but also recognized. ${ }^{37}$

In Indonesia, Sukarno argued, that the ideals of Indonesia's independence were communal life by holding a representative body of the people. In this institution, Islamic laws may be included as long as they get the approval of the members, which is why it is recommended that Muslims win a majority seat in parliament, and keep separating religion from political life. Soekarno's ideas arose from Islamic circles including Muhammad Natsir's response that assessing a situation in the Islamic world using Western references is not objective, because in their eyes there is an a priori feeling towards what smells of Islam. ${ }^{38}$

Harun Nasution stated that no proposition explains the obligation to establish an Islamic state, even regarding the country, there is no "verse or hadith" that clearly says the formation of government or state in Islam. Therefore, for Nurcholish Madjid, although there is no need to establish an Islamic state, as a state society should be able to form an Islamic community. Islamic culture is a society that follows the times in the political, economic, socio-cultural, and legal fields.

Abdurahman Wahid stated that in Islam, there is no form of the state at all. In Islam, there is a social code of ethics; the reason is that Islam recognizes definitive government. ${ }^{39}$ Furthermore, Nurcholish Madjid stated that Islam was not an ideology because the opinion of Islam as an ideology would equate this religion with the doctrines in the world..$^{40}$ Meanwhile, according to Rusydi, Hamka rejected the concept of separation of religion and state. According to him, the teachings of Islam knew nothing about

37 Bahtiar Effendy, Politisasi Islam, Pernah Islam Berhenti Berpolitik?, (Bandung: Mizan, 2000), p. 191; Ali Akhbar Abaib Mas Rabbani Lubis, "Religious Nation State: Bahtiar Effendy and Islamic Political Thought," Millah, vol. 19, no. 2 (2020), pp. 167-98, https://doi.org/10.20885/millah.vol19.iss2.art1.

${ }^{38}$ Muhammad Ishak, "Hubungan Antara Agama Dengan Negara Dalam Pemikiran Islam," Jurnal Tahkim, vol. 10, no. 2 (2014), p. 118, http://jurnal.iainambon.ac.id/index.php/THK/article/ download/54/pdf.

${ }^{39}$ Abdullah, "Hubungan Agama Dan Negara: Konteks KeIndonesiaan,” Jurnal Politik Profetik, vol. 4, no. 2 (2014), pp. 26-27, https://doi.org/10.24252/profetik.v2i2a5.

${ }^{40}$ Dedy Djamaluddin Malik and Idy Subandy Ibrahim, Zaman Baru Islam Indonesia: Pemikiran \& Aksi Politik Abdurrahman Wahid, M. Amien Rais, Nurcholish Madjid, Jalaluddin Rakhmat, (Bandung: Zaman Wacana Mulia, 1998), p. 169. the separation of religion and state because the founding of a country is based more on rational considerations rather than based on the Shari'a texts.

With power, then what is aspired to such as the application of shari'a, worship, and muamalah in Islam can be guaranteed to run safely as expected. Therefore, upholding religion will be challenging to achieve without power, because power will provide free space to support doctrine. ${ }^{41}$ Based on the explanation above, Indonesia is not in one of the three paradigms. But the Indonesian state falls into the category of a secularistic paradigm and a symbiotic (substantial) paradigm, though not wholly. The secularistic model in the Indonesian nation is a separation between religion and state. Indonesia is a country that adheres to a democratic government system that adopts the Dutch law Kitab Undang-Undang Hukum Pidana and Kitab Undang-Undang Hukum Perdata-. But here it is not entirely secular because in Indonesia's national law there is also a transformation of Islamic law - Law Number 1 of 1974 concerning Marriage, Government Regulation Number 28 of 1977 concerning Owned Land Waqf, Law Number 7 of 1989 concerning Parallel to Other Judicial Institutions, Law Number 17 of 1999 concerning the Implementation of Hajj, Law Number 38 of 1999 concerning Management of Zakat, Law Number 10 of 1998 concerning Sharia Banking with the principles for profit sharing. This is an indication that the Indonesian state is also included in the category of symbiotic (substantial) paradigms, because in national law, there are laws derived from Islamic values.

\section{Ulama and Umara in the Indonesian Government}

Carrying out politics and maintaining the ideology of the state is not only the job of politicians and diplomats, but also it is the joint responsibility of the people who live in a country. In this case, especially the cooperation of the ulama is needed. ${ }^{42}$ Ulama have the science of religion that can be used to foster social and not only religious knowledge but ulama also has what is called a charismatic authority ${ }^{43}$ that can influence the community to

\footnotetext{
${ }^{41}$ Muhammad Ishak, "Hubungan Antara Agama..., p. 120.

${ }^{42}$ Sholeh Fikri, "Posisi Ulama..., p. 70.

43 Nasution, "Komunikasi Dakwah Ulama Sumatera
} 
be obedient to worship Allah. The ulama are also the place where people ask for their opinions, their advice is heard, and their orders - to obey Allah Swt and His Messenger - are done.

According to the history, it is difficult to trace when the term ulama became part of the Islamic tradition. The initial information at least that can be a reference is when the Prophet Muhammad was in Medina, there was a part of the community (Muslims) at that time devoted themselves to deepen the problem of religion ${ }^{44}$-noted a group of people who like to sit outside (porch/ overhanging) Medina mosque called Ahl al-Shuffah-. Ulama are demanded to be able to develop the values contained in the Quran to answer the challenges of the times which are always changing from time to time and increasingly complex both in the political, economic, legal, social, and cultural fields. But in daily life, the ulama must set good examples or examples of good morals for the community. ${ }^{45}$

According to the significant role of government ulama forming the Indonesian Ulama Council (MUI) on July 26,1975 . This organization functions to:

1) provide guidance and guidance to Indonesian Muslims in realizing religious and community life that is blessed by Allah; 2) provide advice and fatwas on religious and social issues to the government and the community to increase activities for the realization of the Ukhwah Islamiyah and harmony among religious communities in strengthening the unity and integrity of the nation; 3) liaising between ulama and umara (government) and reciprocal translators between the ummah and the government to succeed national development; 4) improve relations and cooperation between organizations, Islamic institutions and Muslim ulama in providing guidance and guidance to the community, especially Muslims, by holding mutual consultation and information. ${ }^{46}$

Selatan (Studi Terhadap Jenis-Jenis Komunikasi Dakwah K. H. Muhammad Zen Syukri)," p. 17; Compare, with Ahmad Zainal Arifin, "Charisma and Rationalisation in a Modernising Pasantren: Changing Values in Traditional Islamic Education in Java", (University of Western Sidney, 2013), p. 6.

44 Zionis, "KONSEP KENEGARAAN DALAM ISLAM: Perdebatan Relasional Yang Tak Kunjung Tuntas," p. 115.

${ }^{45}$ M. Quraish Shihab, Membumikan Al-Qur'an..., p. 385.

${ }^{46}$ Majelis Ulama Indonesia (MUI), "Sejarah MUI," 2020, https://mui.or.id/sejarah-mui/, accessed on February 11, 2020.
When viewed from the history of the attitude of the ulama, there are several kinds. ${ }^{47}$ First, ulama who cooperate with the authorities. The ulama who cooperate with the authorities can be seen from the case of the establishment of the madrasa established by the Bani Fatimiah in Cairo where the ulama as executors and teachers in the madrasa collaborated with the government which had set certain streams to be taught in the subjects in the madrasa and also spread propaganda for the state schools of power; Second, ulama who keep their distance from the authorities are ulama who do not interfere in state affairs. They only teach, preach independently, and even there is no intervention from the government, Min. Abd alQadir al-Jilani -A founder of the Qodariyah troupe who kept a distance from power and fostered the people independently, lectured, taught, and founded madrasas-;4 ${ }^{48}$ Third, Ulama takes a position as an opposition to the authorities. This attitude was taken because the authorities had violated and disobeyed the commands of Allah Swt, for example, Ahmad bin Hanbal. He was a victim of the mihnah -in the time of al-Mamun, he imposed a policy of mihnah against the ulama which was not in line with the ideology of the Quran conquests derived from the Mu'tazilah doctrine- which was practised by the Abbasiyah authority.

In the context of Indonesian ulama, the ulama can be said to keep their distance from the authorities and not appear as the opposition. But some elements think that some ulama in Indonesia are in opposition so that they are executed and intimidated. For example, Abdul Somad, he had never opposed the authorities -he was even invited to state institutions such as the Indonesian People's Consultative Assembly (MPR-RI) ${ }^{49}$ - but he was intimidated. This is very unsettling for some people because they feel disadvantaged that the sermon to be delivered by Abdul Somad is cancelled. At the time of the cancellation of the

47 Ismail, "Ulama Dan Pendidikan Islam Klasik (Kajian Ulama, Status Sosial, Kekuasaan, Pendidikan, Dan Gerakan Intelektual)," pp. 92-95.

${ }^{48}$ Ismail, "Ulama..., p. 95.

49 Tribunnews.com, "Ustaz Abdul Somad Tampil Sebagai Penceramah Dalam “"MPR RI Bersholawat,"”' 2018, https:// www.tribunnews.com/nasional/2018/08/29/ustaz-abdul-somadtampil-sebagai-penceramah-dalam-mpr-ri-bersholawat?page=all, accessed on February, 11, 2020. 
lecture, the community did not get knowledge from ulama. The government cannot remain silent because if this action is allowed to continue, it will continue. Here the government needs to take firm action against those who carry out the persecution and intimidation of the ulama to clarify the motive for the work must even be processed through law if the party is proven guilty.

According to al-Ghazali stated that the damage to its authority caused the actual cost to the people, and the loss of the ulama caused the damage to the authorities, and the value of the ulama was due to the love of wealth and position, and whoever was controlled by worldly ambitions he would not be able to take care of the little people, let alone its authority. Allah is the place to ask for everything..$^{50}$

Based on al-Ghazali's statement above, it can be seen that the importance of personal self-correction for an ulama. Because in da'wah, one must use a polite manner so as not to offend others. As the word of Allah in Surah al-Nahl [16]: 125:

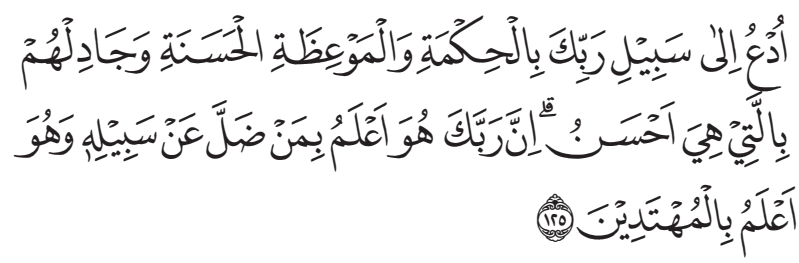

Invite to the way of your Lord with wisdom and proper instruction, and argue with them in a best way. Indeed, your Lord is most knowing of who has strayed from His way, and He is most knowing of who is (rightly) guided. ${ }^{51}$ (Q. S.16: 125)

According to Fakrudin al-Razy in preaching, it is recommended to use clear and definite propositions as well as specific considerations based on common sense so that the intent to be conveyed can be achieved. ${ }^{52}$ Muhammad ash-Shawy said that there are three methods of da'wah, namely wisdom, mau'idhah hasanah, and mujadalah is the best. Meanwhile, according to M. Quraish Shihab, to the laity, it was ordered to apply mau'idhah hasanah, ie to give advice and imagery that touches the soul by their simple level and knowledge. ${ }^{53}$

${ }^{50}$ Abu Hamid Al-Ghazali, Ihya 'Ulumuddin, (Beirut: Dar Kutub al-Ilmiyah, n.d.), Juz. II p. 381.

51 Departemen Agama RI, Al-Quran Dan Terjemahnya, (Bandung: Syaamil Qur'an, 2010), p. 281.

52 Fakhruddin Al-Razy, Tafsir Mafatih Al-Ghaib, (Libanon: Dar Kutub al-Ilmiyah, 1990), Juz. 20, p. 295.

${ }^{53}$ M. Quraish Shihab, Tafsir Al-Misbah, (Jakarta: Lentera
It cannot be separated from that; the leader must help the ulama in dakwah not to leave the ulama. Ulama can be used as a place to ask for advice from leaders. Also, a leader must also be careful, not just any cleric who must be asked for help. For example, the ulama su' (evil ulama) will plunge the country into destruction..$^{54}$ For this reason, a leader is close to the people, paying attention to all groups to avoid favouritism towards the people. The state is obliged to assist the people to maximize life on earth with full responsibility. The mental and physical condition of every community must be protected wisely. .5

Regarding to this issue, it can be concluded that religious and state affairs cannot be separated. Likewise, with the ulama and umara cannot be separated because without the ulama, the country will experience a crisis of religious knowledge, and also without umara, religion cannot be applied correctly.

\section{Conclusion}

Indonesia is not included of the three paradigms -secularistic paradigms, formalistic (intergalactic) paradigms, and symbiotic (substantial) paradigmsbut Indonesia is included in the category of a secularistic paradigm and a symbiotic (substantial) paradigm, although not entirely. In Indonesia, there is a separation between religion and state, as is the secularistic model, but not entirely secularistic. In Indonesia's national law, there is also a transformation of Islamic law. This is an indication that the Indonesian state is also included in the category of symbiotic (substantial) paradigms, because there are laws derived from Islamic values in national legislation.

In the relationship between religion and the state, the ulama provides balance to the umara. According to history of the attitude of the ulama towards authority, there are several kinds; First, ulama who want to cooperate with the authorities. Ulama who cooperate with the authorities; Second,

\footnotetext{
Hati, 2002), Volume. 7, p. 287.

${ }^{54}$ Kholili Hasib, "Konsep Siyasah Dan Adab Bernegara Menurut Imam Al-Ghazali,” Falasifa, vol. 1, no. 1 (2017), p. 9, https://doi.org/10.36835/falasifa.v8i1.35.

${ }_{55}$ Abu Hamid Al-Ghazali, Fadail Al-Batiniyah, (Beirut: Maktabah al-'Ashriyah, 2001), p. 205.
} 
there are ulama who keep their distance from the authorities. Ulama who keep their distance from the authorities, namely by teaching, preaching independently, even there is no intervention from the government; Third, there are also times when ulama take a stand in opposition to the authorities. This attitude was taken because the authorities had violated and disobeyed the commands of Allah Swt.

Religion and state affairs cannot be separated. Likewise, the ulama and umara cannot be separated because without the ulama, the country will experience a crisis of religious knowledge and also without umara the religion cannot be applied correctly. Religion must be the axis, and the authority is the guardian, and something that has no guardian will surely be destroyed. Therefore, the cooperation of ulama and umara in the government of a country is necessarily required so that religion can be implemented correctly within a country.

\section{References}

Aakvaag, Gunnar C, "3 A Democratic Way of Life: Institutionalizing Individual Freedom in Norway." Democratic State and Democratic Society, 2018. https://doi. org/10.1515/9783110634082-004.

Abdillah, Masyukuri, Demokrasi Di Persimpangan Makna; Respon Intelektual Muslim Indonesia Terhadap Konsep Demokrasi 1966-1930. Yogyakarta: Tiara Wacana, 1999.

Abdullah, "Hubungan Agama Dan Negara: Konteks Ke-Indonesiaan." Jurnal Politik Profetik, vol. 4, no. 2 2014. https://doi.org/10.24252/profetik. v2i2a5.

Abyhara, Abu Bakar, Pengantar Ilmu Politik, Yogyakarta: Ar-Ruzz Media, 2010.

Albab, Ulil, "Studi Pemikiran Mohammad Natsir Tentang Islam Sebagai Dasar Negara." UIN Walisongo Semarang, 2016.

Arief, Abd. Salam, "Relasi Agama Dan Negara Dalam Perspektif Islam," Hermeneia: Jurnal Kajian Islam Interdisipliner, vol. 2, no. 2, 2003. http://digilib.uin-suka.ac.id/8422/.

Arifin, Ahmad Zainal, "Charisma and Rationalisation in a Modernising Pasantren: Changing Values in Traditional Islamic Education in Java," University of Western Sidney, 2013.

Arnold, Denis G, "Corporations and Human Rights Obligations." Business and Human
Rights Journal, vol. 1, no. 2, 2016. https://doi. org/10.1017/bhj.2016.19.

Azra, Azyumardi, Pergolakan Politik Islam. Jakarta: Paramadina, 1996.

Chirzin, Muhammad. "Ulama Dan Umara Dalam Perspektif Al-Qur'an,” accessed February 9, 2020. http://malang.muhammadiyah.or.id/ content-133-sdet-ulama-dan-umara-dalamperspektif-alqur'an.html.

Daradjat, Zakiyah, Ilmu Jiwa Agama, Jakarta: Bulan Bintang, 2005.

Departemen Agama RI, Al-Quran Dan Terjemahnya, Bandung: Syaamil Qur'an, 2010.

Edge, Matt, "A Theory of Freedom." European Journal of Political Theory, vol. 12, no. 4, 2013. https://doi.org/10.1177/1474885112473721.

Effendy, Bahtiar, "Islam and the State in Indonesia: Munawir Sjadzali and the Development of Anew Theological Underpinning of Political Islam." Studia Islamika, vol. 2, no. 2, 1995. https://doi.org/10.15408/sdi.v2i2.836.

_- Politisasi Islam, Pernah Islam Berhenti Berpolitik? Bandung: Mizan, 2000.

Efrinaldi, "Spektrum Fikih Siyasah Dan Dinamisasi Politik Islam Di Indonesia." Madania,vol. 17, no. 1, 1991. https://doi.org/10.29300/madania. v17i1.2839.

Farizi, Mudrik Al, "Konfigurasi Pemikiran Relasi Islam Dan Negara Di Indonesia." Al Mabsut: Jurnal Studi Islam Dan Sosial, vol, 10, no. 2, 2016. https://ejournal.iaingawi.ac.id/index.php/ almabsut/article/view/158.

Fikri, Sholeh, "Posisi Ulama Dalam Pemerintahan Kota Padangsidimpuan," TAZKIR: Jurnal Penelitian Ilmu-Ilmu Sosial Dan Keislaman, vol. 2, no. 1, 2016. https://doi.org/10.24952/tazkir. v2i1.402.

Ghazali Al-, Intisari Ihya 'Ulumiddin, (Penerjemah) Junaidi Ismaiel, Jakarta: Serambi Semesta Distribusi, 2016.

—, Abu Hamid, Fadail Al-Batiniyah, Beirut: Maktabah al-'Ashriyah, 2001.

_- Ihya 'Ulumuddin, Beirut: Dar Kutub alIlmiyah, n.d, Juz. II.

Hamka, Lembaga Hidup. Jakarta: Republika Penerbit, 2016.

Hasib, Kholili, "Konsep Siyasah Dan Adab Bernegara Menurut Imam Al-Ghazali." Falasifa, vol. 1, no. 1, 2017. https://doi.org/10.36835/falasifa.v8i1.35. 
Ilyas, Yunahar, Kuliah Akhlaq, Yogyakarta: Lembaga Pengkajian dan Pengalaman Islam (LPPI), 1999. Ishak, Muhammad, "Hubungan Antara Agama Dengan Negara Dalam Pemikiran Islam." Jurnal Tahkim, vol. 10, no. 2, 2014. http:// jurnal.iainambon.ac.id/index.php/THK/article/ download/54/pdf.

Ismail, Ahmad Nur, "Ulama Dan Pendidikan Islam Klasik (Kajian Ulama, Status Sosial, Kekuasaan, Pendidikan, Dan Gerakan Intelektual)." Jurnal Media Pendidikan Agama Islam, vol. 1, no. 1, 2014. http://ejournal.kopertais4.or.id/susi/ index.php/jmpai/login.

Ismail, Faisal, Paradigma Kebudayaan Islam: Studi Krisis Dan Refleksi Historis, Yogyakarta: Titian Ilahi Press, 1997.

Katadata.co.id, "Jumlah Penduduk Indonesia Menurut Agama (2010-2050)," 2019. https:// databoks.katadata.co.id/datapublish/2019/09/24/ bera pa-jum la h-penduduk-mus lim indonesia?utm=viva43v3r.

Kiblat.net, “Evaluasi 2017, Persekusi Ulama Hingga Pembubaran Pengajian Jadi Sorotan," 2017. https://www.kiblat.net/2017/12/31/evaluasi2017-persekusi-ulama-hingga-pembubaranpengajian-jadi-sorotan/.

Lubis, Ali Akhbar Abaib Mas Rabbani, "Religious Nation State: Bahtiar Effendy and Islamic Political Thought." Millah, vol. 19, no. 2, 2020. https://doi.org/10.20885/millah.vol19.iss2.art1. Majelis Ulama Indonesia (MUI), "Sejarah MUI," accessed on February 11, 2020. https://mui. or.id/sejarah-mui/.

Malik, Dedy Djamaluddin, and Idy Subandy Ibrahim, Zaman Baru Islam Indonesia: Pemikiran \& Aksi Politik Abdurrahman Wahid, M. Amien Rais, Nurcholish Madjid, Jalaluddin Rakhmat, Bandung: Zaman Wacana Mulia, 1998.

Mauk, Marlene, "Disentangling an Elusive Relationship: How Democratic Value Orientations Affect Political Trust in Different Regimes," Political Research Quarterly, vol. 73, no. 2, 2020. https://doi.org/10.1177/1065912919829832.

Menzies, Allan, Sejarah Agama-Agama, Yogyakarta: Forum, 2014.

Merdeka.com, “Ustaz Abdul Somad Sebut Diintimidasi \& Batalkan Ceramah Di Jawa, Ini Kata Polisi," 2018. https://www.merdeka.com/ peristiwa/ustaz-abdul-somad-sebut-diintimidasibatalkan-ceramah-di-jawa-ini-kata-polisi.html.
Miles, Matthew B., and A. Michael Huberman, Qualitative Data Analysis (a Source Book of New Methods), Beverly Hills: Sage Publications, 1984. Mohammad, Ibnu Manzur Jamal al-Din, Lisan AlArab, Kairo: al-Dar al-Misriyah, n.d, Juz 15.

Mawardi, Al-, Al-Ahkam Al-Sulthaniyah, Kuwait: Maktabah Dar Ibnu, 1989.

Nasution, Nurseri Hasnah, "Komunikasi Dakwah Ulama Sumatera Selatan (Studi Terhadap JenisJenis Komunikasi Dakwah K. H. Muhammad Zen Syukri)," Jurnal Komunikasi Islam Dan Kehumasan (JKPI), vol. 2, no. 1, 2018. https:// doi.org/10.19109/jkpi.v2i1.2750.

Razy, Al-, Fakhruddin, Tafsir Mafatih Al-Ghaib, Libanon: Dar Kutub al-IImiyah, Juz. 20, 1990.

Shihab, M. Quraish, Membumikan Al-Qur'an. Bandung: Mizan, 1995.

—. Tafsir Al-Misbah, Jakarta: Lentera Hati, Volome 7, 2002.

Sjadzali, Munawir, Islam Dan Tata Negara. Jakarta: Universitas Indonesia, 1993.

Supriadi, Yogi, "Hubungan Agama Dan Negara Dalam Perspektif Aksi Bela Islam.” Jaqfi: Jurnal Aqidah Dan Filsafat Islam, vol. 1, no. 2, 2017. https://doi.org/10.15575/jaqfi.v1i2.1713.

Tribunnews.com, "Ustaz Abdul Somad Tampil Sebagai Penceramah Dalam “"MPR RI Bersholawat,"'" 2018. https://www.tribunnews. com/nasional/2018/08/29/ustaz-abdul-somadtampil-sebagai-penceramah-dalam-mpr-ribersholawat?page=all.

Wahid, Abd, "Pola Peran Ulama Dalam Negara Di Aceh," Madania, vol. 17, no. 1, 2013. https:// doi.org/10.29300/madania.v17i1.2845.

Zaman, Muhammad Qasim, The Ulama in Contemporary Islam, Custodians of Change, Princeton \& Oxford: Princeton University Press, 2002.

Zaprulkhan, "Relasi Agama Dan Negara Dalam Perspektif Islam," Walisongo, vol. 22, no. 1, 2014. https://doi.org/10.21580/ws.22.1.261.

Zionis, Rijal Mumazziq, “KONSEP KENEGARAAN DALAM ISLAM: Perdebatan Relasional Yang Tak Kunjung Tuntas." Falasifa, vol. 1, no. 2. 2010. https://jurnalfalasifa.files.wordpress. com/2012/11/8-rijal-mumazziq-zionis-konsepkenegaraan-dalam-islam-perdebatan-relasionalyang-tak-kunjung-tuntas.pdf. 